\title{
ON SOME POGONOPHORA FROM THE NORTH- EAST ATLANTIC, INCLUDING TWO NEW SPECIES
}

\author{
By Eve C. Southward and A. J. Southward \\ The Plymouth Laboratory
}

(Text-figs. I-3)

In the course of dredging for the rich epifauna of the continental slope near $48^{\circ} 30^{\prime} \mathrm{N}$., $10^{\circ} \mathrm{W}$. (Southward \& Southward, 1958b) in May 1957, several hauls were made by chance on a muddy bottom at 500-700 fm. depth. At the time, these hauls were examined only cursorily after sieving, and the contents immediately preserved. One of the hauls contained several damaged siliceous sponges, and a recent careful examination disclosed a number of pogonophore tubes entangled among the threads and spicules of the sponges.

TABLE 1. RECORDS OF POGONOPHORA FROM THE CONTINENTAL SLOPE

\begin{tabular}{|c|c|c|c|c|}
\hline Date & Position & $\begin{array}{c}\text { Depth } \\
(\mathrm{fm} .)\end{array}$ & Bottom deposit & $\begin{array}{l}\text { Species of } \\
\text { Siboglinum found }\end{array}$ \\
\hline 4. v. 57 & $48^{\circ} 28^{\prime}$ N., $10^{\circ} 04^{\prime} \mathrm{W}$. & 700 & $\begin{array}{l}\text { Mud containing a little } \\
\text { sand and foramini- } \\
\text { feran shells }\end{array}$ & $\begin{array}{l}\text { S. atlanticum, } \\
\text { S. inermis, } \\
\text { S. ekmani }\end{array}$ \\
\hline \multirow{5}{*}{ I7. v. 58} & $48^{\circ} 32^{\prime} \mathrm{N} ., 10^{\circ} 10^{\prime} \mathrm{W}$. & $670-720$ & Mud and a few stones & S. atlanticum \\
\hline & $48^{\circ} 3 \mathrm{I}^{\prime}$ N., $10^{\circ} \mathrm{II}^{\prime} \mathrm{W}$. & $520-680$ & Mud and some gravel & S. atlanticum \\
\hline & $47^{\circ} 56^{\prime}$ N., $7^{\circ} 57^{\prime}$ W. & $340-350$ & Mud containing sand & \\
\hline & $47^{\circ} 50^{\prime}$ N., $7^{\circ} 57^{\prime} \mathrm{W}$. & $300-450$ & Mud containing sand & S. inermis \\
\hline & $47^{\circ} 50^{\prime}$ N., $8^{\circ} 08^{\prime}$ W. & $670-710$ & $\begin{array}{l}\text { Mud and cretaceous } \\
\text { rocks }\end{array}$ & S. atlanticum \\
\hline
\end{tabular}

Nearly forty tubes, of three types, were found in this haul, most of them containing the animal in a good state of preservation (Southward \& Southward, I958a). Further searches among our collections have brought to light some empty tubes taken in two other hauls on the same cruise of R.V. 'Sarsia'. Once it was known that Pogonophora were present on the continental slope further dredging was arranged, and to date (June 1958) these interesting animals have been taken alive at three more stations (Table I).

Although three species have been obtained, all belong to the genus Siboglinum Caullery. This was the first genus of the group to be described, and $S$. weberi remained for a long time the only known representative (Caullery, 1914, 1944). Later the Class name Pogonophora was suggested 
(Johansson, 1937) for Lamellisabella zachsi Uschakov. Siboglinum was assigned to this group by Ivanov, who erected a new phylum of the Deuterostomia, Phylum Brachiata A. Ivanov, for the group (Ivanov, I95I, I955). Investigations in the Pacific and Arctic oceans have revealed many new genera and species of pogonophores, while recently a species of Siboglinum has been discovered in deep water in the Skagerak (Jägersten, 1956; Ivanov, 1957; Kirkegaard, 1958). The Pogonophora are thus becoming well known, and their occurrence in the Atlantic Ocean proper is not unexpected.

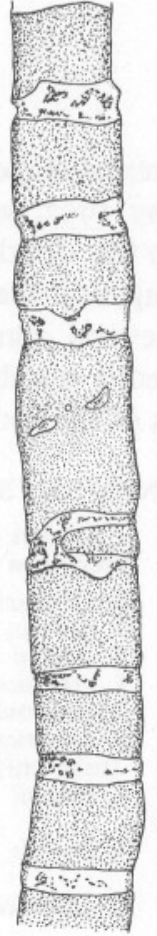

A

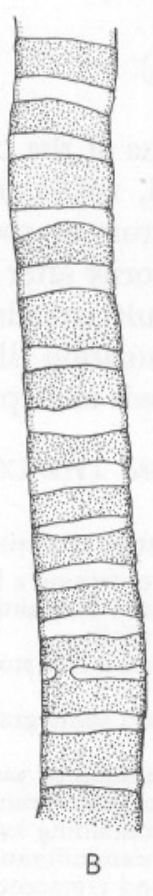

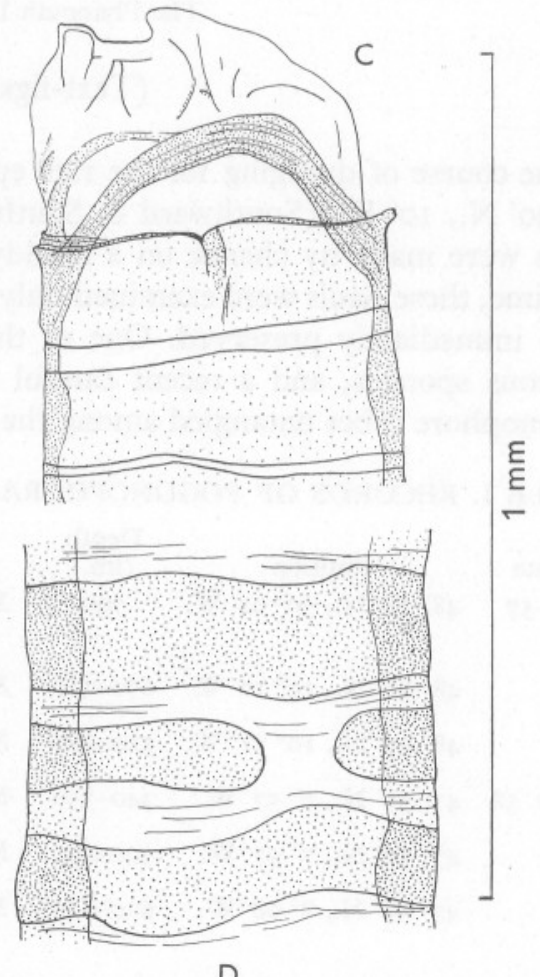

D

Fig. I. Appearance of tubes: A, Siboglinum inermis; B, S. ekmani; c, anterior end of tube of $S$. atlanticum; $\mathrm{D}$, middle of tube of $S$. atlanticum.

Of the three species included in this work, one is the Scandinavian species $S$. ekmani. The other two appear to be new, even though seven species of Siboglinum have already been described (Ivanov, 1957), omitting $S$. weberi which appears to include more than one species. The two new species are described first below, followed by some notes on our specimens of S. ekmani. Later we hope to deal with the biology of these animals, and to describe further species taken in only $80-90 \mathrm{fm}$. off the west coast of Ireland. 
Siboglinum atlanticum sp.nov.

From twenty tubes of this species we obtained parts of fourteen animals. The two longest tubes were 40 and $32 \mathrm{~cm}$ long; most of the shorter ones were obviously incomplete. The diameter of each tube was about $0.42 \mathrm{~mm}$ near the anterior end, increasing to about $0.5 \mathrm{~mm}$ in the middle. The general colour was pale brownish grey, and the walls were ringed as shown in Fig. I D.
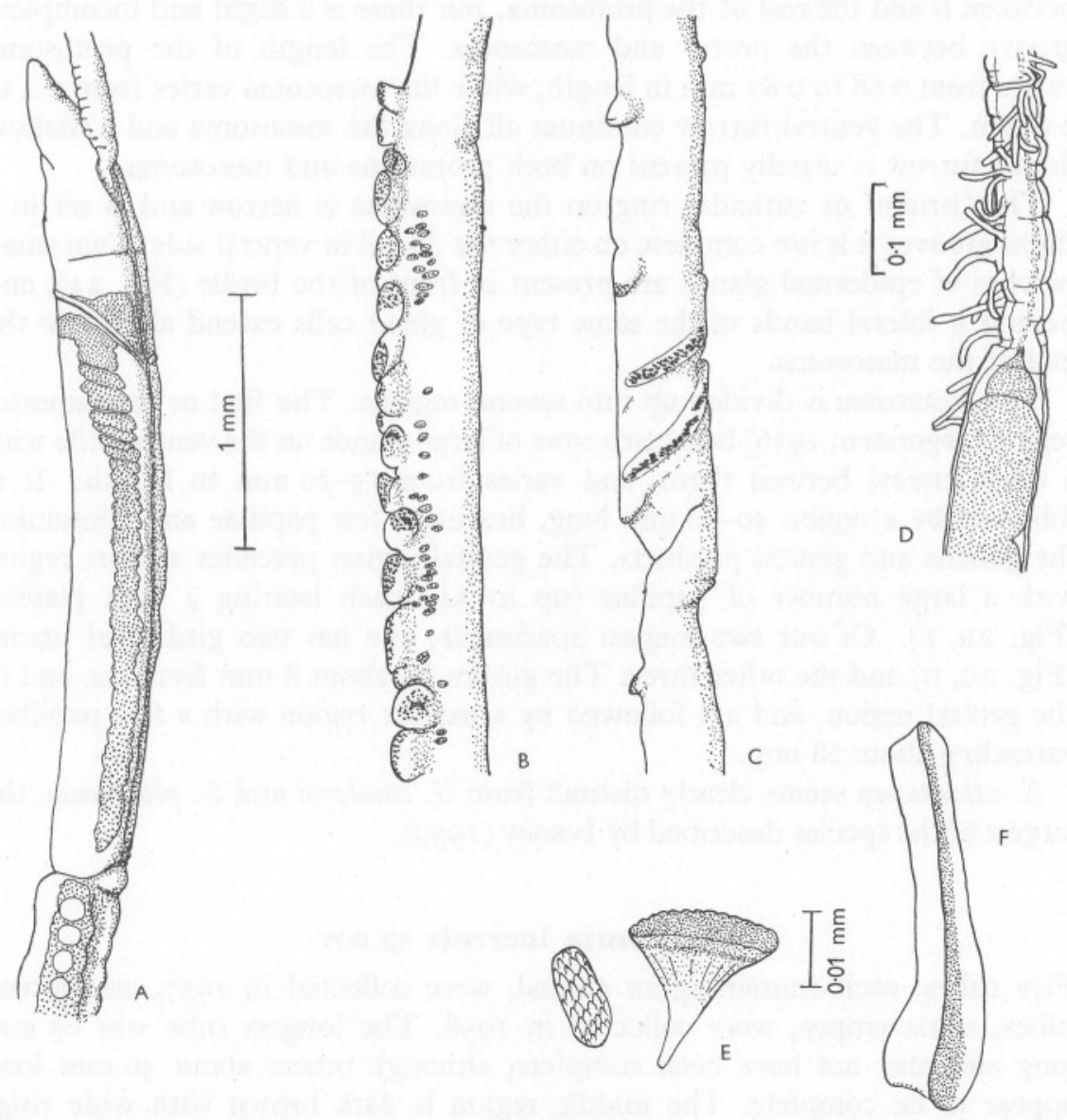

Fig. 2. Siboglinum atlanticum: A, anterior end, lateral view; B, part of region with papillae, lateral view; $\mathrm{C}$, girdle region, lateral view; $\mathrm{D}$, part of tentacle; $\mathrm{E}$, uncini, surface and side view; F, platelet from one of the papillae, side view.

The anterior end is paler and in most cases is sealed by an extension of the tube lining (Fig. I C). Seven to Io $\mathrm{cm}$ below this end is a brown mark, not more than I cm long, which may indicate the surface of the mud.

The two longest animals are both about $13 \mathrm{~cm}$ long, excluding the tentacle, 
which may reach $2 \mathrm{~cm}$ in length. The other specimens are anterior ends up to $4 \mathrm{~cm}$ long. The tentacle is usually coiled up in preserved material; it bears two rows of pinnules set close together and in many specimens it is distended with blood for all or parts of its length (Fig. 2D). The blood is bright red in living specimens and brown when preserved. The tentacle rises from a furrow on the ventral side (Fig. 2A), and its junction with the body is narrow. The dorsal lobe is small and pointed, with no perceptible groove between it and the rest of the protosoma, but there is a slight and incomplete groove between the proto- and mesosoma. The length of the protosoma varies from 0.68 to $0.87 \mathrm{~mm}$ in length, while the mesosoma varies from 2.4 to $2.9 \mathrm{~mm}$. The ventral furrow continues all along the mesosoma and a shallow dorsal furrow is usually present on both protosoma and mesosoma.

The 'bridle' or cuticular ring on the mesosoma is narrow and is set in a slight groove; it is not complete on either the dorsal or ventral side. Two small patches of epidermal glands are present in front of the bridle (Fig. 2A), and behind it lateral bands of the same type of gland cells extend almost to the end of the mesosoma.

The metasoma is divided up into several regions. The first or 'metameric' region (Jägersten, 1956) bears two rows of large glands on the ventral side with a deep furrow betwen them, and varies from $15-20 \mathrm{~mm}$ in length. It is followed by a region $40-50 \mathrm{~mm}$ long, bearing a few papillae and containing the gonads and genital products. The genital region precedes a short region with a large number of papillae (up to 34, ) each bearing a dark platelet (Fig. 2B, F). Of our two longest specimens, one has two girdles of uncini (Fig. 2C, D) and the other three. The girdles lie about $8 \mathrm{~mm}$ from the end of the genital region, and are followed by a narrow region with a few papillae, extending about $28 \mathrm{~mm}$.

$S$. atlanticum seems clearly distinct from $S$. caulleryi and $S$. plumosum, the largest of the species described by Ivanov (1957).

\section{Siboglinum inermis sp.nov.}

Five tubes, each containing an animal, were collected in 1957, and fifteen tubes, some empty, were collected in 1958. The longest tube was $65 \mathrm{~mm}$ long and may not have been complete, although others about $50 \mathrm{~mm}$ long appear to be complete. The middle region is dark brown with wide rings (Fig. IA). These rings are almost opaque, and it is difficult to see the animal inside. Both ends of the complete tubes are colourless. The diameter of the tube ranges from 0.13 to $0.18 \mathrm{~mm}$. The complete animal varies from 13.5 to $25 \mathrm{~mm}$ long, with a tentacle up to $3 \mathrm{~mm}$ long. The tentacle, in preserved and living specimens, is entirely without pinnules, and the specific name refers to this. The anterior part of the body varies from 0.70 to $0.96 \mathrm{~mm}$ in length, of which the protosoma forms $\mathrm{I} / 5$ to $\mathrm{I} / 4$ (Fig. $3 \mathrm{~A}$ ). The narrow bridle is com- 
plete ventrally, but broken dorsally; a faint longitudinal groove runs along the ventral side of the mesosoma (Fig. 3A, B). It is difficult to distinguish epidermal glands on the mesosoma, but there seem to be at least two small patches just behind the bridle. The metasoma is short compared with that of S. ekmani; in one complete female it is $14 \mathrm{~mm}$ long, of which $5 \mathrm{~mm}$ carries metameric glands, $3 \mathrm{~mm}$ contains ovaries, $2 \mathrm{~mm}$ has a few papillae (without platelets), which are followed by the girdles and about $4 \mathrm{~mm}$ with a few papillae. Of

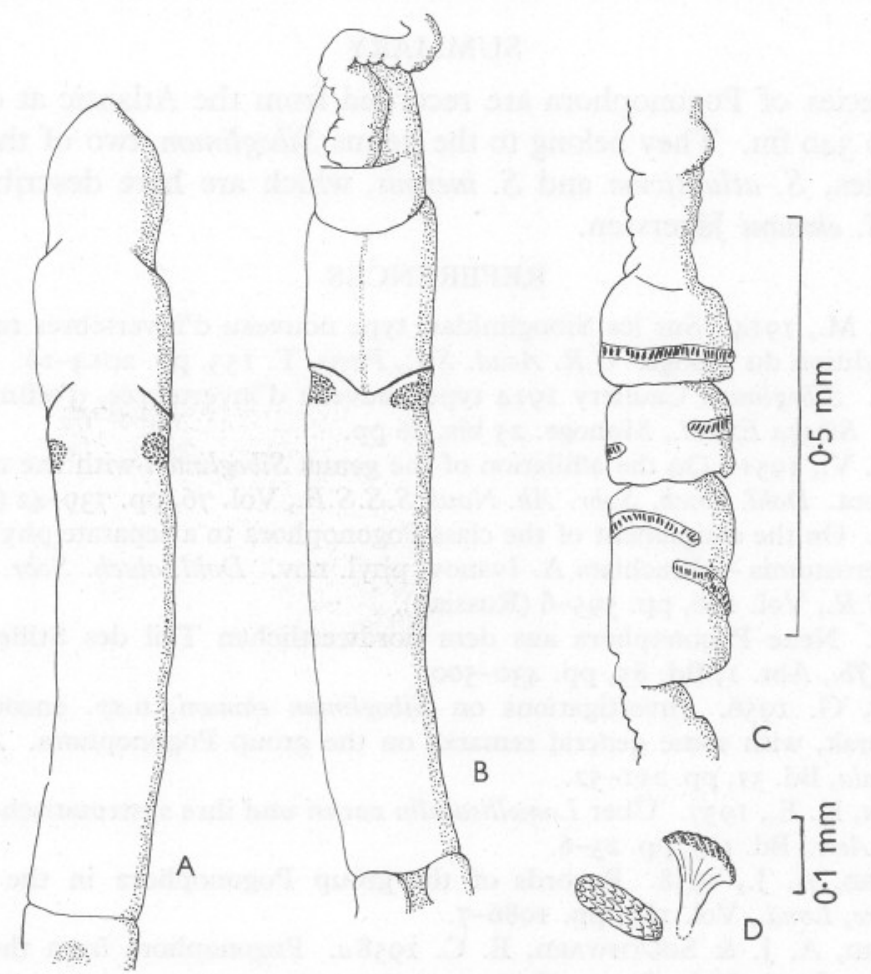

Fig. 3. Siboglinum inermis: A, anterior end, dorsal view; B, anterior end, ventral view; C, girdle region; D, uncini, surface and side view.

six specimens with complete girdle regions, two have three girdles and four have two. Each girdle is made up of a single row of uncini (Fig. 3C, D).

This species differs from S. ekmani in the type of tube, the diameter, the proportions of the body and in having a tentacle without pinnules.

\section{Siboglinum ekmani Jägersten}

The specimens described by Jägersten (1956) were incomplete, but our specimens agree with his description in the form (Fig. I B) and size of the tube, in the proportions of the body and in having two rows of pinnules on the 
tentacle. In our specimens the length of the longest tube was $10.5 \mathrm{~cm}$, and the complete animal would appear to be about $30 \mathrm{~mm}$ long. The 'endobody' noted by Jägersten must have been produced by damage or preservation, since our specimens have a girdle region similar to $S$. inermis, except for the arrangement of the girdles. Each is composed of one row of uncini; the first and second are less than $0.2 \mathrm{~mm}$ apart, while the third is at least $\mathrm{I} .5 \mathrm{~mm}$ behind the second. In one specimen there is a further Io $\mathrm{mm}$ of body behind the girdles.

\section{SUMMARY}

Three species of Pogonophora are recorded from the Atlantic at depths of 710 up to $340 \mathrm{fm}$. They belong to the genus Siboglinum, two of them being new species, $S$. atlanticum and $S$. inermis, which are here described. The third is $S$. ekmani Jägersten.

\section{REFERENCES}

CaUllery, M., I9I4. Sur les Siboglinidae, type nouveau d'invertébrés recueilli par l'expedition du Siboga. C.R. Acad. Sci., Paris, T. I53, pp. 2014-16.

- 1944. Siboglinum Caullery I914 type nouveau d'invertébrés, d'affinités à préciser. Siboga Exped., Monogr. 25 bis, 26 pp.

Ivanov, A. V., I95I. On the affiliation of the genus Siboglinum with the class Pogonophora. Dokl. obsch. Sobr. Ak. Nauk S.S.S.R., Vol. 76, pp. 739-42 (Russian).

- 1955. On the assignment of the class Pogonophora to a separate phylum of the Deuterostomia - Brachiata A. Ivanov, phyl. nov. Dokl. obsch. Sobr. Ak. Nauk S.S.S.R., Vol. 100, pp. 595-6 (Russian).

- 1957. Neue Pogonophora aus dem nordwestlichen Teil des Stillen Ozeans. Zool. fb., Abt. I, Bd. 85, pp. 430-500.

JäGERSTEN, G. I956. Investigations on Siboglinum ekmani, n.sp. encountered in Skagerak, with some general remarks on the group Pogonophora. Zool. Bidr. Uppsala, Bd. 31, pp. $211-52$.

Johansson, K. E., I937. Úber Lamellisabella zachsi und ihre systematische Stellung. Zool. Anz., Bd. I 17, pp. 23-6.

KIRKEGAARD, A. J., I958. Records of the group Pogonophora in the Skagerak. Nature, Lond., Vol. I8I, pp. I086-7.

Southward, A. J. \& Southward, E. C. I958a. Pogonophora from the Atlantic. Nature, Lond., Vol. I8I, p. I607.

- $1958 \mathrm{~b}$. On the occurrence and behaviour of two little-known barnacles, Hexelasma hirsutum and Verruca recta, from the continental slope. F. mar. biol. Ass. U.K., Vol. 37, pp. 633-647. 